https://doi.org/10.26593/jihi.v17i1.3728.31-46

\title{
Comparative Analysis of The Indonesia-China High-Speed Train Project and The KTX Korea-France: A Sustainable Development for Locals or Reconfiguring Other Interests
}

\author{
Darynaufal Mulyaman ${ }^{1}$, Kanya Damarçanti ${ }^{2}$ \\ ${ }^{1}$ Dept. of International Relations, Universitas Kristen Indonesia, Indonesia, darynaufal.mulyaman@uki.ac.id \\ ${ }^{2}$ Indonesian Institute of Advanced International Studies (INADIS), damarcanti@inadis.com
}

\begin{abstract}
ABSTRAK
Studi ini meneliti tentang perkembangan kerja sama antara Indonesia dan Cina terkait kereta api berkecepatan tinggi dan konstruksi pendukungnya. Jalur kereta baru, teknologi kereta, dan Transit Oriented Development (TOD) adalah bagian dari proyek yang direncanakan bersamaan di sepanjang area proyek. Kendati demikian, jalur kereta baru dan terutama Transit Oriented Development (TOD) dibangun jauh dari tempat tinggal dan pusat bisnis yang sudah ada. Penelitian ini mengemukakan bagaimana proyek ini bermula hingga faktor-faktor krusial mengenai proyek Kereta Cepat Indonesia-Cina. Bercermin dari bagaimana Korea dan Prancis menangani proyek KTX (Korean Train Express), TOD, jalur kereta api, hingga teknologi kereta api terhadap proyek KCIC, KCIC seperti tidak mengusung keberlanjutan dan digerakkan oleh kepentingan politik dan ekonomi lainnya.
\end{abstract}

Kata Kunci: Cina; Kereta Cepat; Indonesia; Korea; Kerja Sama

\begin{abstract}
This study examines the recent development of cooperation between Indonesia and China regarding the highspeed railway and its supporting constructions. New dedicated railway, train technology, and Transit-Oriented Development (TOD) are part of the initial project, which is planned concurrently along the projected area. All of these new railways and TODs are new and distant from already built residences and business centers. This study breakdown how the Indonesia-China High-Speed Train project was initiated and explaining the vital factors that surround it. Reflecting on how Korea and France dealt with KTX (Korean Train Express) project, the TODs, railways, and train technology compared to the Indonesia-China High-Speed Train project, the Indonesia-China project appears not sustainable and driven by another political and economical will.
\end{abstract}

Keyword(s): China; High-Speed Train; Indonesia; Korea; Cooperation

\section{Introduction}

The Jakarta-Bandung High-Speed Railway (JBHSR) is one of Indonesian President Joko "Jokowi" Widodo's aspiring framework improvement plans. This venture, which is supported primarily by an advance from China, will cut travel time between the two biggest urban communities in Java (Jakarta and Bandung) from around three to five hours by car or by customary railroads to only 40 minutes. On October 6, 2015, Jokowi issued Presidential Regulation (Peraturan Presiden [Perpres])
No.107/2015 on the acceleration of framework and offices and assigned the Indonesia-China High-Speed Rail Consortium (PT Kereta Cepat Indonesia China [PT $\mathrm{KCIC}]$ ) - a cooperation between the Pilar Sinergi BUMN Indonesia Consortium (PBSI) and the China Railroad Worldwide Co.Ltd. (CRI) to implement at the project $^{1}$.

\footnotetext{
${ }^{1}$ Salim, Wilmar and Siwage Dharma Negara, (2016). Why is the High-Speed Rail Project So Important to Indonesia? ISEAS Perspective No.16, 2016.
} 
32 Darynaufal Mulyaman \& Kanya Damarçanti | Comparative Analysis of The Indonesia-China High-Speed Train Project and The KTX Korea-France: A Sustainable Development for Locals or Reconfiguring Other Interests

PBSI itself is a combination of four Indonesian state owned enterprises (SOEs), namely PT Wijaya Karya (WIKA), PT Kereta Api Indonesia (KAI), PT Perkebunan Nusantara VIII (PTPN VIII), and PT Jasa Marga ${ }^{2}$. Sutianto ${ }^{3}$ stated that at the start of the agreement, the CRI had a 40-percent stake, whereas PBSI had a 60-percent stake. In PBSI, WIKA had a 38-percent stake, KAI and PTPN VIII each had a 25-percent stake, and Jasa Marga had a 12percent stake.

Additionally, Jokowi signed Perpres No.3/2016 on January 8, 2016 ${ }^{4}$, which included the JBHSR venture in the acceleration of 12 vital national projects. He also went to the groundbreaking ceremony of the JBHSR project in Walini, West Java, on January 21, 2016. This move astounded the public, as most of the essential licenses such as the development permit and concession license had not been obtained when the ceremony was held.

Even though Jokowi had marked two Presidential Regulations to accelerate the processing of the JBHSR venture, the development of the high-speed railroads remains hampered due to the long land-clearance issue. The development of the JBHSR was planned from mid-2016 to the conclusion of 2018, while the operation was scheduled to begin in 2019 with roughly 50 years of the concession period. However, as of March 2019, or more than three

${ }^{2}$ Rezkisari, Indira. (2015). Bangun Kereta Cepat, Konsorsium BUMN-Cina Dibentuk. https://republika.co.id/berita/ekonomi/makro/15/10/16/nwa rda328-bangun-kereta-cepat-konsorsium-bumn-cinadibentuk (Accessed July 24, 2019).

${ }^{3}$ Sutianto, Feby Dwi. (2016). Pengembang Kereta Cepat Jakarta-Bandung Suntik Modal Rp 1,25 T.

https://finance.detik.com/berita-ekonomi-bisnis/d3116023/pengembang-kereta-cepatjakarta-bandung-suntikmodal-rp-125-t (Accessed April 3, 2019)

${ }^{4}$ Kementerian Hukum dan HAM Republik Indonesia. (2016). Perpres No.3/2016. Jakarta.

Kementerian Hukum dan HAM Republik Indonesia. (2008). Peraturan Pemerintah [PP] No.26/2008. Jakarta. years after the groundbreaking ceremony, only $94 \%$ (134 kilometers of a total of 143 kilometers) of land had been acquired.

The sluggish land-clearance was not without a consequence, particularly when it came to the credit payment from the China Development Bank (CDB). CDB initially agreed to sign the advance assertion after 100 percent of the land has been legitimately acquired. Nonetheless, CDB compromised to proceed although the land had not been completely cleared after Jokowi changed the Government Regulation (Peraturan Pemerintah [PP]) No.26/2008 to incorporate the JBHSR project within the National Spatial Arrangement (Rencana Tata Ruang Wilayah [RTRW]). After Jokowi's attendance at the Belt and Road Initiative (BRI) Summit in Beijing, CDB disbursed US\$500 million in May 2018 as the first stage of credit, followed by US $\$ 274.8$ million in September 2018.

According to KS PusLit $\mathrm{BKD}^{5}$, The slow progress of the JBHSR was also inseparable from the controversy over the issuance of the environmental permits and the outcomes of the Environmental Impact Assessment (Analisis Dampak Lingkungan [AMDAL]) in 2016. Furthermore, the JBHSR venture had abused several Indonesian laws on environmental, spatial, transportation, and business in its development, like production and protected forest that had been misused into the development of railways and stations.

Thus, similar developments by Korea and France in KTX cooperation invited curiosity to conduct this study. The similarities in developing high-speed train services by Indonesia and Korea invite curiosities in how

\footnotetext{
${ }^{5}$ KS PusLit BKD. (2016). Kontroversi Izin Lingkungan Proyek Kereta Cepat Jakarta-Bandung. https://www.academia.edu/28836139/04 Kontroversi Izin Lingkungan Proyek Kereta Cepat Jakarta-Bandung (Accessed on July 12, 2019)
} 
different the management of developing rail lines, train technologies, land development, management construction, and even cooperation between the partnered countries and the respective government despite the one is still progressing in construction and one already running. KTX TODs were developed by a cooperation between the Korean government and France's company, Alstom. In their master plan, Korean and French cooperation renewing and revamping old stations to oblige KTX trains rather than make a few new stations or committed railroads that are difficult to completely incorporate with the previously existing frameworks or offices, for example, open transportation or business focus. Thus, JBHSR developments choose to build another way. The JBHSR partnership decided to make completely new rails, new stations, and far from population centers, like Tegalluar, in outskirt Bandung regency, West Java.

Considering the number of laws violated in the development process of the JBHSR venture but then continuing and building new stations that are far from population and transportations centers, then, how is the comparison between the JBHSR Indonesia-China partnership and the KTX Korea-France partnership being taken and benefiting the respective host country? This study argues mainly that the development of the JBHSR and its TODs will not bring major any sustainable benefits, politically and economically, for the locals and the benefited partners due to the lack of feasibility study and the number of laws violated yet still proceed. Therefore, this study's main aim is to compare the sustainability projected benefit, planning, and project management/policies of two similar projects that also involve foreign partners.
Furthermore, previous studies such as $\mathrm{OECD}^{6}$ explained that transportation policymakers need more knowledge about the impact of projects and strategies on the economy, industry, competitiveness, economic development, economic mobility, and other public interests needed to guarantee the investments deliver benefits to the community that outweighs the costs of achieving them. Jin $\mathrm{Kim}^{\mathrm{s}}{ }^{7}$ work showed that the value premiums from better accessibility to stations seem to exist, but they decay with increasing distance from the center and correlate with the development densities around station areas. It means that better access to a TOD with a great amount of density provides a better outcome in terms of profit and investment that make the value of property higher.

Then, Johnston argued that local builders are influenced by transportation infrastructure in an urban environment ${ }^{8}$. Further, Wang et al explained that transportation infrastructure has a huge effect on long-term sustainability ${ }^{9}$. However, Lee et al said that social effects from urban transportation programs are usually manifested by focusing on the multi-scale spatial improvements caused by projects over time, as well as the degree to which those changes satisfy diverse needs in project outcomes ${ }^{10}$.

${ }^{6}$ OECD. (2002). Impact of Transport Infrastructure Investment on regional development. OECD.

${ }^{7}$ Kim, Jin. (2007). Discriminant Impact of Transit Station Location on Office Rent and Land Value in Seoul: An Application of Spatial Econometrics. Journal of Transport Economics and Policy. 41. 219-245.

8 Johnston, G. (2013). The impact of transport

infrastructure on the development of urban communities. University of Westminster: London.

${ }^{9}$ Wang, L., Xue, X., Zhao, Z., \& Wang, Z. (2018). The Impacts of Transportation Infrastructure on Sustainable Development: Emerging Trends and Challenges. International journal of environmental research and public health, 15(6), 1172.

https://doi.org/10.3390/ijerph15061172

10 Juhyun, Lee et al. (2020). Examining the Social Outcomes from Urban TransportInfrastructure: Long-Term Consequences of SpatialChanges and Varied Interests at 
34 Darynaufal Mulyaman \& Kanya Damarçanti | Comparative Analysis of The Indonesia-China High-Speed Train Project and The KTX Korea-France: A Sustainable Development for Locals or Reconfiguring Other Interests

Additionally, Khanani et $\mathrm{al}^{11}$ said that largescale strategic planning and urban infrastructure programs are becoming increasingly common in cities in the Global South. Such schemes are used to boost accessibility, increase city attractiveness, and, as a result, encourage investment.

Moreover, Jaimu Won ${ }^{12}$ said that functional, economic, and multi-criteria evaluations could inform the choice of sets of varied transportation systems and urban settlement, especially in Korea. Cadena et $\mathrm{al}^{13}$ said, "today the rise of emerging-market cities is significant because these urban centers are proving to be the world's economic dynamos, attracting workers and productive business". It means that emerging market cities if being developed and given the correct management could be a motor of growth and locomotive of change, and thus promoting the cities to be more advanced. Jasjit Singh ${ }^{14}$ also said, "Geographic localization of knowledge spillovers is a central tenet in multiple streams of research". Therefore, the location and localization are important for planning a development that encourages sustainability and spillover from technology that is applied in the development process.

Multiple Levels. Sustainability 2020,12, 5907; doi:10.3390/su12155907

11 Khanani, Risper Sarah et al. (2020). The Impact of Road Infrastructure DevelopmentProjects on Local Communities in Peri-urban areas: the Case of Kisumu, Kenya, and Accra, Ghana. International Journal of Community WellBeinghttps://doi.org/10.1007/s42413-020-00077-4 12 Won, J. (1990). Multicriteria Evaluation Approaches to Urban Transportation Projects. Urban Studies, 27(1), 119138. Retrieved from http://www.jstor.org/stable/43084074 (Accessed, July 20, 2019)

${ }^{13}$ Cadena, A., Dobbs, R., \& Remes, J. (2012). The Growing Economic Power of Cities. Journal of International Affairs, 65(2), 1-17. Retrieved from http://www.jstor.org/stable/24388214 (Accessed on July 10, 2019)

${ }^{14}$ Singh, Jasjit, and Matt Marx. (2012). Geographic Constraints on Knowledge Spillovers: Political Borders vs. Spatial Proximity. INSEAD.
Thus, an integrated urban transport, combination of long-range train and LRT for example, is an encouraging business model yet not further researched in the feasibility studies of TODs, Lavery, and Kanaroglou ${ }^{15}$ said that "LRT as a means for encouraging real estate development in the vicinity transit stops, and due to its real and perceived advantages over buses, LRT is also seen by public transportation providers as an opportunity to increase public transportation's modal share. Integrated Urban Model (IUM) which characterizes the relationship between land use, transportation, and activities to project what impacts the LRT line will have".

Then, Yang and Pojani ${ }^{16}$, Falconer and Richardson $^{17}$, Renne ${ }^{18}$, and Huang and Shuai ${ }^{19}$ deliberately explore what kind of needs for a city to be a transit-oriented city, in Australia, the US, and China. A transit-oriented city involves intense, mixed development around transit nodes. Similar to Yang and Pojani ${ }^{20}$ have said that "The level of concentration of population, dwellings, and jobs in rail-based TOD nodesas opposed to areas that are unserved by the train

${ }^{15}$ Lavery, Thomas and Pavlos Kanaroglou. (2012).

Rediscovering light rail: assessing the potential impacts of a light rail transit line on transit-oriented development and transit ridership. Transportation Letters, 4:4, 211-226, DOI: 10.3328/TL.2012.04.04.211-226

${ }^{16}$ Yang, Katie and Dorina Pojani. (2017). A Decade of Transit Oriented Development Policies in Brisbane, Australia: Development and Land-Use Impacts. Urban Policy and Research, 35:3, 347-362, DOI:

10.1080/08111146.2017.1294537

${ }^{17}$ Falconer, Ryan, and Emmerson Richardson. (2010). Rethinking urban land use and transport planning opportunities for transit-oriented development in Australian cities case study Perth. Australian Planner, 47:1, 1-13, DOI: 10.1080/07293680903510519

${ }^{18}$ Renne, John L. (2009). From transit-adjacent to transitoriented development. Local Environment, 14:1, 1-15, DOI: $10.1080 / 13549830802522376$

${ }^{19}$ Huang, Wencheng and Bin Shuai. (2019). Approach and application on high-speed train stop plan for better passenger transfer efficiency: the China case. International Journal of Rail Transportation, 7:1, 55-78, DOI: $10.1080 / 23248378.2018 .1489741$

20 ibid 
network". Meanwhile, Chang and Chang ${ }^{21}$ in their research conduct an elaborate discovery for deciding market-share for a high-speed train, "variable time value, for estimating the market share of high-speed rail (HSR) in the northwestsoutheast (NW-SE) corridor of Korea currently served by air, conventional rail, and highway modes". Then, Robertson ${ }^{22}$ researches "utilizing a 'bottom-up approach, the projected effect on $\mathrm{CO} 2$ emissions of a modal shift from short-haul air travel to high-speed rail (HSR), based on projected passenger movements".

To sum up, collected previous research indicated that there is no research about comparing two similar projects in one coherent framework about complementarity, relation, and spatial connection regarding their projected benefit, planning, and policy/management. Therefore, this study is trying to fill the gap in that particular field. Hence, comparison analysis between two projects becomes imminent for this study. A new way of comparing could be a new filling for conduct in this kind of study further.

\section{Methods}

This paper will be conducted through comparative analysis by qualitative desk study sourced from official documents or statements, news, and other studies resources. Therefore, with comparative analysis, this paper will compare Indonesia China High-Speed Train Project with KTX Project in terms of how does the project benefit local people who live surrounding the transit-oriented developments

\footnotetext{
${ }^{21}$ Chang, Iljoon and Ganglen Chang. (2004). A networkbased model for estimating the market share of a new high-speed rail system. Transportation Planning and Technology, 27:2, 67-90, DOI: $10.1080 / 0308106042000218186$

${ }^{22}$ Robertson, Simon. (2013). High-speed rail's potential for the reduction of carbon dioxide emissions from short-haul aviation: a longitudinal study of modal substitution from an energy generation and renewable energy perspective.

Transportation Planning and Technology, 36:5, 395-412, DOI: $10.1080 / 03081060.2013 .818271$
}

(TODs) and the train tracks. Furthermore, are these benefits sustainable and visible to the project? Thus, in comparing the cases, this paper will use variables from Sung-Hoon Lim as framework concepts that will be discussed in later parts of this paper.

To analyze the comparison, this article will use the paradigm that has been used by SungHoon Lim in his paper titled "How Beneficial Would the Construction of a Rason-Hunchun Sub-Regional Economic Cooperation Zone in the Northeast Asian Borderlands Be?" as a base paradigm for comparing how a development area could be successful since Sung Hoon Lim explored what factors and how to observe the benefit of a jointly partnered development cooperation. Sung-Hoon $\mathrm{Lim}^{23}$ explained that there are three basic conditions for development, namely economic complementarity, political harmonization, and spatial proximity. Therefore, economic complementarity, political harmonization, and spatial proximity are used as variables in comparison methods between the JBHSR and the KTX TODs.

Economic complementarity is a scheme for complementarity in the economic sector. In a broader meaning, economic complementarity can also be defined as the complementarity effect of the development project to current infrastructures and facilities to induce more benefit to a greater number of people that will utilize the development project and to complete each current infrastructures or facilities to sustain the efficiency of the whole system. Good development is a development that gives benefit to one partner, but both partners and the entire stakeholders in the development project. In

\footnotetext{
${ }^{23}$ Lim, S. (2015). How Beneficial Would the Construction of a Rason-Hunchun Sub-Regional Economic Cooperation Zone in the Northeast Asian Borderlands Be? North Korean Review, 11(1), 63-81. Retrieved from http://www.jstor.org/stable/43908956 (Accessed on July $15,2019)$
} 
terms of the JBHSR project, this article will analyze the economic complementarity between Indonesia and China and its impacts on the local economy in both countries. Complementarity and competition levels are also examined briefly in other areas such as foreign direct investment, capital flows, energy, and other primary products.

Political harmonization is a perspective of seeing a harmonization of relations and synchronizing all policy between two countries regarding the project of development, from the national level to local level. In the RasonHunchun SECZ project between China and North Korea, political harmonization can be seen in the national policies regarding economic relations between the two countries. There were mutual efforts between China and North Korea to ensure the success of the Rason-Hunchun development project. In 2005, China's State Council passed a bill about the Chang Ji-Tu project, a joint Rason Free Economic Trade Zone within three provinces around it. Meanwhile, the North Korean government drafted more than 78 laws such as Economic District Law, Foreign Investment Law, and Joint Work Law to regulate the development project. Therefore, concerning the financial complementarity of cooperation and development, policy harmonization between governments is of the utmost importance. Using this paradigm, this article will examine the political harmonization between China and Indonesia in the JBHSR project.

Spatial proximity can be defined as a distance between two countries to the project site or the distance between the project site to the nearest city or business center. Spatial proximity also includes the demographic of the development project location. Before a development project takes place, the developers have to plan and know how people commute and live, whether the project site is close to the city or business center, and what kind of existing infrastructures and facilities are available in the area. If a development project location was located far from the already existing infrastructures, facilities, or business centers, a loss could occur in the future and jeopardize the project budget and expenditure. The profit, investment, environment requirement, permission clearness, law, and other added values are important for a development project since they can bring benefit and multiple effects even for the neighboring societies.

\section{Analysis}

\section{a. Economic Complementarity of The JBHSR/KCIC \& The KTX}

According to PT Kereta Cepat Indonesia China (PT KCIC) ${ }^{24}$, the Jakarta-Bandung HSR (JBHSR) was built with at least five expected socioeconomic benefits in mind: a) job creation (direct employment) especially to local workers; b) local content development; c) transit-oriented development (TOD) around the railway's four stations; d) traffic congestion alleviation and cut in travel cost and time; and e) government income increase from taxes (PT Kereta Cepat Indonesia China, n.d.). Although more of a spill off of the JBHSR construction, to which China is not part of its development, the TOD alone is forecasted to have a total valuation of IDR 362 trillion (USD 26.8 billion), of which is expected to generate profit around IDR 95-100 trillion (USD 7-7.4 billion). As a comparison, the total investment for HSR and the TOD area building is USD 6.071 billion. Additionally, the cooperation scheme offered by China also includes land acquisition, no funding from the state budget, no underwriting, and no tariff subsidy worth USD 5.13 billion. These offers

${ }^{24}$ PT. Kereta Cepat Indonesia Cina. (2016). Konsep Pembangunan Terintegrasi.

http://kcic.co.id/konsep-pembangunan-terintegrasi/ (Accessed on July 13, 2019) 
37 Darynaufal Mulyaman \& Kanya Damarçanti | Comparative Analysis of The Indonesia-China High-Speed Train Project and The KTX Korea-France: A Sustainable Development for Locals or Reconfiguring Other Interests

cater to the Government of Indonesia's demands and were not in Japan's - China's contenderproposal.

Although at face value China seems not to generate many economic benefits from the project, Syailendra ${ }^{25}$ said it's more of an indirect benefit. If successfully implemented, it would open up opportunities for other projects in Indonesia. Other benefits are, among others, Yafei ${ }^{26}$ said that to accommodate China's excess capacity — of workers and manufacturing; for the Chinese companies to utilize and perchance develop their products, such as drilling machine for the JBHSR construction; to gain more understanding and experiences of conducting business and/or investing in a diverse context, both geographically and socioeconomically; and to receive firsthand information regarding business opportunities, e.g. in the four TOD areas.

Then, in terms of rail technology, the JBHSR will use trains that come from China. Hamdani ${ }^{27}$ explained that the JBHSR will use CR400AF trains that were developed by CRRC Qingdao Sifang. Indonesia's Ministry of Transportation in Yati $^{28}$ (2021) explained that

\footnotetext{
${ }^{25}$ Syailendra, E. A. (2015). Indonesia's High-Speed Rail: A China-Japan Scramble for Influence? RSIS Commentary No. 269-9 December 2015.

http://futuredirections.org.au/wpcontent/uploads/2016/01/CO15269.pdf (Accessed on July 23, 2019)

${ }^{26}$ Yafei, $\bar{H}$. (2014). China's Overcapacity Crisis Can Spur Growth Through Overseas Expansion. https://www.scmp.com/comment/insightopinion/article/1399681/chinas-overcapacity-crisis-canspur-growth-through-overseas (Accessed on July 22, 2019) ${ }^{27}$ Hamdani, Trio. (2020). Rangkaian Kereta Cepat Made in China Tiba di RI 2020.

https://finance.detik.com/infrastruktur/d4706161/rangkaian-kereta-cepat-made-in-china-tiba-di-ri2020 (Accessed on April 11, 2021)

${ }^{28}$ Yati, Rahmi. (2021). Kereta Cepat Jakarta Bandung Terapkan Teknologi Tinggi Menhub Minta Transfer Knowledge.

https://ekonomi.bisnis.com/read/20210411/98/1379402/ kereta-cepat-jakarta-bandung-terapkan-teknologi-tinggi-
}

they hope there will be transfer technology in the JBHSR; therefore we could see that the transfer knowledge is still in the talk or discussion phase rather than already become a concrete policy. Furthermore, Indonesia's Ministry of Transportation stated that cooperation of this high-tech project needs to be followed by the transfer of knowledge between the two parties, thus Indonesia's side of this partnership is still waiting for the signal of transfer technology in the JBHSR partnership.

Moreover, Indonesia's Parliament or Dewan Perwakilan Rakyat (DPR) ${ }^{29}$ pushed the Indonesian Government through the National Railway Corporation (KAI) to be the operator of the JBHSR. It means until this paper is written, the KAI is not directly involved in the development of the JBHSR train operation plan. This particular point indicated that the economic complementarity is an unbalanced state as only Chinese investors are actively dealing with train operation plans.

KTX Project is a high-speed train project from South Korea that originated from the French National Railway Company's (SNFC) research in 1972-1974. This project is linking Seoul in the northern part to further south of the peninsula in Busan to ease congestion between two cities. The construction was started in 1992 and a year later the TGV Consortium was selected to be the supplier of the train-set and engineering supports for rolling stock and railways. Sunduck ${ }^{30}$ also added that"regarding

menhub-minta-transfer-knowledge (Accessed on April 11 2021)

${ }^{29}$ CNN Indonesia. (2020). DPR Minta KAI Protes Bila Tak Jadi Operator Kereta Cepat. https://www.cnnindonesia.com/ekonomi/2020021021250 6-92-473429/dpr-minta-kai-protes-bila-tak-jadi-operatorkereta-cepat (Accessed on April 11, 2021)

${ }^{30}$ Sunduck D.Suh. (2000). Risk Management in a LargeScale New Railway Transport System Project: Evaluation of Korean High-Speed Railway Experience. IATSS Research Volume 24, Issue 2, 2000, Pages 53-63. 
38 Darynaufal Mulyaman \& Kanya Damarçanti | Comparative Analysis of The Indonesia-China High-Speed Train Project and The KTX Korea-France: A Sustainable Development for Locals or Reconfiguring Other Interests

rolling stock, the TGV consortium was selected as a priority negotiation partner in August 1993, and after almost one year, the contract for rolling stock procurement was signed in June 1994".

South Korea and France jointly conducted the project by a consortium led by Eukorail (now Alstom Korea) and Alstom. The consortium structure also includes Hyundai Rotem, Samsung, Hanjin, Daewoo, LGIS, and CSEE of France. This consortium funded 55\% of the total budget of the KTX, whereas the South Korean Government funded the remaining $45 \%$. KTX is unique because it uses a combination of new and existing railways. KTX is also a unique project because it allows a big number of technology transfer schemes from France to South Korea. Cha Nam-Geon and Chung Jin-Kyu ${ }^{31}$ said that the usage of new and existing railways was attributed to the identical tracks of the new and existing railways. Moreover, South Korea has already used this gauge $(1,435 \mathrm{~mm})$ for railways since 1899 .

Unlike China and Indonesia in the KCIC project, the complementarity of the economy for South Korea and France in the KTX project is more visible. South Korea received the technology that was being used for the second development of the KTX train, in which local components were used. Sunduck ${ }^{32}$ stated, "The South Korean Ministry of Science and Technology and the Ministry of Industry and Resources played a big role in developing technology transfer schemes”. Meanwhile, France almost gained a big profit since Alstom Korea was established. On the Alstom website,

\footnotetext{
${ }^{31}$ Nam-Geon Cho and Jin-Kyu Chung. (2008). High-speed rail construction of Korea and its impact. KRIHS Special Report Series. Korea Research Institute for Human Settlements. Anyang.

32 Sunduck D.Suh. (2000). Risk Management in a LargeScale New Railway Transport System Project: Evaluation of Korean High-Speed Railway Experience. IATSS Research Volume 24, Issue 2, 2000, Pages 53-63.
}

Helen Conolly ${ }^{33}$ said, "Eukorail is a Koreanbased subsidiary of ALSTOM, established in 1994 to manage Franco-Korean consortiums for rail projects. The total contract value for ALSTOM was 1.5 billion euros". Furthermore, DoDo from the European Tribune ${ }^{34}$ said that "It (KTX) turned a profit in 2007, and it began to be seen as a success by enough people for calls for extensions to be heard". Therefore, the economic complementarity is visible, even until now, and cooperation between South Korea and France was achieved.

\section{b. Political Harmonization of The JBHSR/KCIC \& The KTX}

Sihite and Lumanauw ${ }^{35}$ said that China's JBHSR proposal offered financial incentives more than Japan's. This became the main reason Indonesia chose to partner with China. Politically, the project is something of a double-edged sword for Jokowi's administration ${ }^{36}$. Partnering with China to conduct such a large-scale project amid the uncontrolled spread of hoaxes and fake news, widespread divisive issues, as well as increasing anti-China sentiment in Indonesia, would be rather unfavorable for Jokowi who was looking for his stability that disturbed by anti-

${ }^{33}$ Conolly, Helen. (2004). KTX Opens for Commercial Service.

https://www.alstom.com/press-releases-news/2004/4/KTXopens-for-commercial-service-20040401 (Accessed on July 17, 2019)

${ }^{34}$ DoDo. (2010). KTX: of delays and

ambitions.https://www.eurotrib.com/story/2010/10/30/2072 $\underline{4 / 383}$ (Accessed on July 19, 2019)

${ }^{35}$ Sihite, Ezra and Novy Lumanauw. (2015). China Says Its High-Speed Railway Package for Indonesia Is 'More Competitive' Than Japan's. https://jakartaglobe.id/business/china-says-high-speedrailway-package-indonesia-competitive-japans/ (Accessed on April 11, 2021)

${ }^{36}$ Rakhmat, Muhammad Zulfikar. Indonesia Makin Bergantung Pada Cina dan Itu Berbahaya: Apa Yang Bisa Dilakukan.

https://theconversation.com/indonesia-makinbergantung-pada-cina-dan-itu-berbahaya-apa-yang-bisadilakukan-150948 (Accessed on April 11, 2021) 
39 Darynaufal Mulyaman \& Kanya Damarçanti | Comparative Analysis of The Indonesia-China High-Speed Train Project and The KTX Korea-France: A Sustainable Development for Locals or Reconfiguring Other Interests

China sentiment. However, the financial incentives offered might as well align with Jokowi's infrastructure and industrial development plans. Moreover, Hutton ${ }^{37}$ also explained, "To win votes, the Indonesian leader needs Chinese cash to build railways and ports. To build those railways and ports he needs to accept the Chinese workers who are losing him votes". It means the Indonesian Government needs a bombastic kind of infrastructure to be done no matter what to sustain the political term of Jokowi rather than real infrastructures that Indonesians need, therefore the project itself is politically contested ${ }^{38}$.

It's important to note that the project was met with a hail of criticism from local NGOs and also violated several domestic laws such as environment ${ }^{39}$ and business laws ${ }^{40}$, to the extent that several local spatial plans and environmental permits had to be altered and/or expedited to meet the set deadlines ${ }^{41}$. As of early July 2019, for instance, the local government in Bandung Barat has yet to grant permission for PT Wijaya Karya (Persero) (hereafter PT WIKA) to develop Walini Station's TOD area-

\footnotetext{
${ }^{37}$ Hutton, Jeffrey. (2018). A Catch-22 from China that could derail Indonesia's Widodo. https://www.scmp.com/weekasia/politics/article/2145806/catch-22-china-could-derailindonesias-widodo (Accessed on April 11, 2021)

${ }^{38}$ Tritto, Angela. (2020). Contentious Embeddedness: Chinese State Capital and the Belt and Road Initiative in Indonesia.

https://madeinchinajournal.com/2020/05/06/contentious -embeddedness-chinese-state-capital-indonesia/

(Accessed on April 11, 2021)

${ }^{39}$ Saeno. (2016). Kereta Cepat Jakarta-Bandung: KCIC Siap Hadapi Gugatan Walhi.

https://ekonomi.bisnis.com/read/20160219/98/520699/k ereta-cepat-jakarta-bandung-kcic-siap-hadapi-gugatanwalhi_(Accessed on April 11, 2021)

${ }^{40}$ Arifin, Choirul. (2016). WALHI: Proyek Kereta Cepat Jokowi Cacat Hukum.

https://www.tribunnews.com/bisnis/2016/02/06/walhiproyek-kereta-cepat-jokowi-cacat-hukum (Accessed on April 11, 2021)

41 Prasetiawan, Teddy. 2016. Kontroversi Izin Proyek Kereta Cepat Jakarta-Bandung. Info Singkat Kesejahteraan Sosial Vol. VIII, No. 04/II/P3DI/Februari/2016
}

Walini Station is one of the JBHSR's four stations. The fact that the project continues and is expedited despite the many hurdles, the GOI seems to put a high expectation on its forecasted benefits.

Meanwhile, for China, the project conveniently comes as an opportunity to increase its economic and political leverage in Indonesia and, internationally, to build credibility and rebrand its image as a technology and innovation powerhouse ${ }^{42}$. This also works in line with China's visions through the Belt Road Initiative (BRI) project, albeit the JBHSR itself - at least initially - is not part of it.

The KTX project was initiated by the South Korean government and received mixed reactions, especially from the environmental specialists, and yet the project was still fully supported by the government even until today's expansion development ${ }^{4344}$. A session was held in the court between the government and the environmental specialists, labeled by the media as "Salamander vs KTX". The environmental specialists were concerned that the development of the KTX near Ulsan would destroy the rare salamander habitat. DoDo ${ }^{45}$ said that the government won the case because "the High Court did not recognize the salamanders as legal persons, and construction proceeded according to original plans. Be it due to fortune or because

42 Paendong, Meiki W. (2020). The Jakarta-Bandung Rail Project: 5 Years On and Still Going Nowhere. https://thediplomat.com/2020/12/the-jakarta-bandungrail-project-5-years-on-and-still-going-nowhere/ (Accessed on April 11, 2021)

${ }^{43}$ Kim Chun-Hwan. (2005). 40 Years of High-speed

Railways Transportation Revolution: The Korean Highspeed Railway. Japan Railway \& Transport Review No. 40 (pp.8-13).

${ }^{44}$ Lee, Juhyung. (2017). KTX: South Korea's high-speed rail network goes from strength to strength https://www.globalrailwayreview.com/article/61573/ktxsouth-koreas-high-speed-rail/(Accessed on April 11, 2021)

${ }^{45}$ DoDo. (2010). KTX: of delays and ambitions.https://www.eurotrib.com/story/2010/10/30/2072 4/383 (Accessed on July 19, 2019) 
40 Darynaufal Mulyaman \& Kanya Damarçanti | Comparative Analysis of The Indonesia-China High-Speed Train Project and The KTX Korea-France: A Sustainable Development for Locals or Reconfiguring Other Interests

builders paid extra attention to avoid negative publicity, no aquifer was drained". Apart from the salamander case, the policy issued by South Korea and France regarding the KTX project was planned carefully and almost without hustle. Therefore there is a kind of mixed reaction toward harmonization between the JBHSR and the KTX project, yet the South Korean Government handling of the KTX project is more sound and straightforward compared to the Indonesian Government handling of the JBHSR project.

\section{c. Spatial Proximity of The JBHSR/KCIC \& The KTX}

On the spatial ground, Indonesia might be seen as the only one to gain the most advantage from the project. However, the cartography of the world can be understood in three ways. In addition to geographical demarcations and political boundaries, there is also the imaginative space that transcends both. In this latter term, especially now with the massive BRI project and its outward-looking visions, China has a stake in it - that is to broaden its sphere of influence in the region ${ }^{4647}$.

In terms of the KTX project, Sunduck ${ }^{48}$ said, "For KTX operation, two new stations were built, two stations were renovated to function as retail and cultural centers in the cities. Other stations were also expanded to accommodate the KTX operation". This particular statement is critical for spatial reasons

\footnotetext{
${ }^{46}$ Ohashi, Hideo. (2018). The Belt and Road Initiative (BRI) in the context of China's opening-up policy. Journal of Contemporary East Asia Studies, 7:2, 85-103, DOI: $10.1080 / 24761028.2018 .1564615$

${ }^{47}$ Ly, Bora and Richard Meissner (Reviewing editor). (2020). China and global governance: Leadership through BRI. Cogent Social Sciences, 6:1, DOI: 10.1080/23311886.2020.1801371

${ }^{48}$ Sunduck D.Suh. (2000). Risk Management in a LargeScale New Railway Transport System Project: Evaluation of Korean High-Speed Railway Experience. IATSS Research Volume 24, Issue 2, 2000, Pages 53-63.
}

because KTX is revitalizing and renovating old stations to accommodate the KTX trains instead of making several new stations or dedicated railways that are hard to fully integrate with the already existing infrastructures or facilities such as public transportation or business centers. With revitalizing and renovating stations and railways, the KTX project saved a lot of budgets to develop localizing high technology trains that they got from TGV France. Hisung Lee and Dae-Sop Moon ${ }^{49}$ said, "During the KTX project of 12 years, Korea's high-speed railroad technology had overcome many technical difficulties and acquired many precious experiences in terms of interfaces of $R / S$ and infrastructures. Those things were adapted and integrated to develop the next generation of KTX which has a technically compatible system for existing infrastructures". It means that compatibility is the keyword to enhance and provide sustainable technology that can adapt to local needs with localizing values.

Thus, geographical demarcations, political boundaries, and imaginative space could overlap each other to create better spatial proximity of joint country projects. Therefore, the geographical demarcations that occur in the JBHSR Project have been proved in such a wasting way to build new stations that are far from business and transportation hubs in each region or city that crossed by this project. Contrast with what Korea and France have done in the KTX Project that was previously explained in this paper.

Then, from political boundaries, Indonesia and China's relations are dynamics. From 'AntiChina' sentiment to the Chinese Belt and Road Initiative debt scheme, a lot of Indonesians tend

\footnotetext{
${ }^{49}$ Hisung Lee and Dae-Sop Moon. (2005). Next Generation of Korean Train Express (KTX): Prospect and Strategies. Eastern Asia Society for Transportation Studies, Vol. 5, pp. $255-262$.
} 
to suspect Beijing' movements ${ }^{50}$. Moreover, even though Indonesian unsure toward China, recently Indonesia' inward-looking style of government undoubtedly matches with Chinese presence and growth in investment that Jokowi' is looking to develop infrastructures ${ }^{51}$. This statement is matched with what Mercy A. Kuo has said, China's Belt and Road Initiative has coincided with Jokowi's domestic infrastructure building focus, which has strengthened ChinaIndonesia ties that have historically been comparatively cooler than others in Southeast Asia. While the influence and investment of China have risen, it has given rise to strong nationalist economic responses.

In imaginative space, we could comprehend values and profits from the JBHSR Project are still debatable in terms of sustainability and profitability $^{52}$. One indication is since this research has found that the JBHSR is not environmentally friendly because of the misuse of production and protected forest that had been incorporated into the development of railways and stations ${ }^{53}$. Moreover, the fast diminishing water catchment areas along the indicated forest inside project areas become a concern in how the JBHSR Project could benefit people, not only economically but also environmentally ${ }^{54}$.

\footnotetext{
${ }^{50}$ Sukma, Rizal. (1994). "Recent Developments in SinoIndonesian Relations: An Indonesian View." Contemporary Southeast Asia 16, no. 1 (1994): 35-45.

${ }^{51}$ Kuo, M. A. (2019). Jokowi 2.0: Indonesia Amid USChina Competition. Retrieved from https://thediplomat.com/2019/11/jokowi-2-0-indonesiaamid-us-china-competition/ (Accessed on November 30 , 2019)

52 Nath, Siddartha, and Raganata Gusti. (2020). An Assessment of Economic and Financial Impacts of JakartaBandung High-Speed Railway Project. JBPE Journal of Business and Political Economy, Vol 2 (1), 2020

53 Lukihardianti, Arie. (2016). Proyek Kereta Cepat, 57 Hektare Hutan Jabar Hilang https://nasional.republika.co.id/berita/nasional/daerah/o 19abl354/proyek-kereta-cepat-57-hektare-hutan-jabarhilang (Accessed on April 11, 2021)

${ }^{54}$ Prasetiyo, B. (2016). Pengamat: Proyek Kereta Cepat Merusak Lingkungan. Retrieved from https://bisnis.tempo.co/read/738527/pengamat-proyek-
}

Hence for some experts like Bagus Prasetiyo, this particular issue becomes a crucial thing to think about.

\section{Conclusion}

Following the comparison above, we can conclude that the JBHSR Project was unprepared and hurried like intended for achieving its target. Even though economically wise, the JBHSR Project could generate profit, bad building transit management, lack of government synchronization, and environmental issues give such negative impacts for Indonesia. Sustainability should be pushed forward rather than only instant economic profit. The transfer of technology and city planning become additional factors that are lacking in the JBHSR Project.

Then, unlike China and Indonesia in the JBHSR/KCIC initiative, South Korea and France's economic complementarity is more evident in the KTX project. The South Korean government initiated the KTX project, which received mixed reactions, particularly from environmental specialists, but the project was still fully supported and cordially managed by the government until today's expansion progress. As a result, there are mixed reactions to the JBHSR and KTX projects' harmonization policies with partnered countries and intended targets, but the South Korean Government's handling of the KTX project is more sound and transparent than the Indonesian Government's handling of the JBHSR project.

kereta-cepat-merusak-lingkungan (Accessed on July 12 2019) 
42 Darynaufal Mulyaman \& Kanya Damarçanti | Comparative Analysis of The Indonesia-China High-Speed Train Project and The KTX Korea-France: A Sustainable Development for Locals or Reconfiguring Other Interests

\section{References}

\section{Book:}

Kementerian Hukum dan HAM Republik Indonesia. (2016). Perpres No.3/2016. Jakarta.

Kementerian Hukum dan HAM Republik Indonesia. (2008). Peraturan Pemerintah [PP] No.26/2008. Jakarta.

OECD. (2002). Impact of Transport Infrastructure Investment on regional development. OECD.

\section{Journal and Research:}

Cadena, A., Dobbs, R., \& Remes, J. (2012). The Growing Economic Power of Cities. Journal of International Affairs, 65(2), 1-17. Retrieved from http://www.jstor.org/stable/24388214 (Accessed on July 10, 2019)

Chang, Iljoon, and Gang-len Chang. (2004). A network-based model for estimating the market share of a new high-speed rail system. Transportation Planning and Technology, 27:2, 67-90, DOI: $10.1080 / 0308106042000218186$

Falconer, Ryan, and Emmerson Richardson. (2010). Rethinking urban land use and transport planning - opportunities for transit-oriented development in Australian cities case study Perth. Australian Planner, 47:1, 1-13, DOI: 10.1080/07293680903510519

Hisung Lee and Dae-Sop Moon. (2005). Next Generation of Korean Train Express (KTX): Prospect and Strategies. Eastern Asia Society for Transportation Studies, Vol. 5, pp. 255 - 262.
Huang, Wencheng and Bin Shuai. (2019). Approach and application on high-speed train stop plan for better passenger transfer efficiency: the China case. International Journal of Rail Transportation, 7:1, 55-78, DOI: $10.1080 / 23248378.2018 .1489741$

Johnston, G. (2013). The impact of transport infrastructure on the development of urban communities. University of Westminster: London.

Juhyun, Lee et al. (2020). Examining the Social Outcomes from Urban TransportInfrastructure: Long-Term Consequences of SpatialChanges and Varied Interests at Multiple Levels. Sustainability 2020,12, 5907; doi:10.3390/su12155907

Khanani, Risper Sarah et al. (2020). The Impact of Road Infrastructure DevelopmentProjects on Local Communities in Peri-urban areas: the Case of Kisumu, Kenya, and Accra, Ghana. International Journal of Community WellBeinghttps://doi.org/10.1007/s42413020-00077-4

Kim Chun-Hwan. (2005). 40 Years of Highspeed Railways Transportation Revolution: The Korean High-speed Railway. Japan Railway \& Transport Review No. 40 (pp.8-13).

Kim, Jin. (2007). Discriminant Impact of Transit Station Location on Office Rent and Land Value in Seoul: An Application of Spatial Econometrics. Journal of Transport Economics and Policy. 41. 219-245. 
43 Darynaufal Mulyaman \& Kanya Damarçanti | Comparative Analysis of The Indonesia-China High-Speed Train Project and The KTX Korea-France: A Sustainable Development for Locals or Reconfiguring Other Interests

Lavery, Thomas and Pavlos Kanaroglou. (2012). Rediscovering light rail: assessing the potential impacts of a light rail transit line on transit-oriented development and transit ridership. Transportation Letters, 4:4, 211-226, DOI:

10.3328/TL.2012.04.04.211-226

Lim, S. (2015). How Beneficial Would the Construction of a Rason-Hunchun SubRegional Economic Cooperation Zone in the Northeast Asian Borderlands Be? North Korean Review, 11(1), 63-81. Retrieved from http://www.jstor.org/stable/43908956 (Accessed on July 15, 2019)

Ly, Bora and Richard Meissner (Reviewing editor). (2020). China and global governance: Leadership through BRI. Cogent Social Sciences, 6:1, DOI: $\underline{10.1080 / 23311886.2020 .1801371}$

Nam-Geon Cho and Jin-Kyu Chung. (2008). High-speed rail construction of Korea and its impact. KRIHS Special Report Series. Korea Research Institute for Human Settlements. Anyang.

Nath, Siddartha, and Raganata Gusti. (2020). An Assessment of Economic and Financial Impacts of Jakarta-Bandung High-Speed Railway Project. JBPE Journal of Business and Political Economy, Vol 2 (1), 2020

Ohashi, Hideo. (2018). The Belt and Road Initiative (BRI) in the context of China's opening-up policy. Journal of Contemporary East Asia Studies, 7:2, 85-103, DOI: $\underline{10.1080 / 24761028.2018 .1564615}$
Prasetiawan, Teddy. 2016. Kontroversi Izin Proyek Kereta Cepat Jakarta-Bandung. Info Singkat Kesejahteraan Sosial Vol. VIII, No. 04/II/P3DI/Februari/2016

Renne, John L. (2009). From transit-adjacent to transit-oriented development. Local Environment, 14:1, 1-15, DOI: $10.1080 / 13549830802522376$

Robertson, Simon. (2013). High-speed rail's potential for the reduction of carbon dioxide emissions from short-haul aviation: a longitudinal study of modal substitution from an energy generation and renewable energy perspective.

Transportation Planning and Technology, 36:5, 395-412, DOI: 10.1080/03081060.2013.81827

Salim, Wilmar and Siwage Dharma Negara, (2016). Why is the High-Speed Rail Project So Important to Indonesia? ISEAS Perspective No.16, 2016.

Singh, Jasjit, and Matt Marx. (2012). Geographic Constraints on Knowledge Spillovers: Political Borders vs. Spatial Proximity. INSEAD.

Sukma, Rizal. (1994). "Recent Developments in Sino-Indonesian Relations: An Indonesian View." Contemporary Southeast Asia 16, no. 1 (1994): 35-45.

Sunduck D.Suh. (2000). Risk Management in a Large-Scale New Railway Transport System Project: Evaluation of Korean High-Speed Railway Experience. IATSS Research Volume 24, Issue 2, 2000, Pages 53-63. 
44 Darynaufal Mulyaman \& Kanya Damarçanti | Comparative Analysis of The Indonesia-China High-Speed Train Project and The KTX Korea-France: A Sustainable Development for Locals or Reconfiguring Other Interests

Wang, L., Xue, X., Zhao, Z., \& Wang, Z. (2018). The Impacts of Transportation Infrastructure on Sustainable Development: Emerging Trends and Challenges. International journal of environmental research and public

health, 15(6), 1172.

https://doi.org/10.3390/ijerph15061172

Won, J. (1990). Multicriteria Evaluation Approaches to Urban Transportation Projects. Urban Studies, 27(1), 119-138. Retrieved from http://www.jstor.org/stable/43084074 (Accessed, July 20, 2019)

Yang, Katie and Dorina Pojani. (2017). A

Decade of Transit Oriented Development Policies in Brisbane, Australia: Development and Land-Use Impacts. Urban Policy and Research, 35:3, 347-362, DOI: 10.1080/08111146.2017.1294537

\section{Online Article:}

Arifin, Choirul. (2016). WALHI: Proyek Kereta Cepat Jokowi Cacat Hukum.

https://www.tribunnews.com/bisnis/2016/02/06/ walhi-proyek-kereta-cepat-jokowicacat-hukum (Accessed on April 11, 2021)

CNN Indonesia. (2020). DPR Minta KAI Protes Bila Tak Jadi Operator Kereta Cepat. https://www.cnnindonesia.com/ekonomi /20200210212506-92-473429/dprminta-kai-protes-bila-tak-jadi-operatorkereta-cepat (Accessed on April 11, 2021)

Conolly, Helen. (2004). KTX Opens for Commercial Service. https://www.alstom.com/press-releasesnews/2004/4/KTX-opens-forcommercial-service-20040401 (Accessed on July 17, 2019)

DoDo. (2010). KTX: of delays and ambitions.https://www.eurotrib.com/stor $\mathrm{y} / 2010 / 10 / 30 / 20724 / 383$ (Accessed on July 19, 2019)

Hamdani, Trio. (2020). Rangkaian Kereta Cepat Made in China Tiba di RI 2020. https://finance.detik.com/infrastruktur/d4706161/rangkaian-kereta-cepat-madein-china-tiba-di-ri-2020 (Accessed on April 11, 2021)

Hutton, Jeffrey. (2018). A Catch-22 from China that could derail Indonesia's Widodo.

https://www.scmp.com/weekasia/politics/article/2145806/catch-22china-could-derail-indonesias-widodo (Accessed on April 11, 2021)

KS PusLit BKD. (2016). Kontroversi Izin Lingkungan Proyek Kereta Cepat Jakarta-Bandung. https://www.academia.edu/28836139/04 _Kontroversi_Izin_Lingkungan_Proyek Kereta_Cepat_Jakarta-Bandung (Accessed on July 12, 2019)

Kuo, M. A. (2019). Jokowi 2.0: Indonesia Amid US-China Competition. Retrieved from https://thediplomat.com/2019/11/jokowi -2-0-indonesia-amid-us-chinacompetition/ (Accessed on November 30, 2019)

Lee, Juhyung. (2017). KTX: South Korea's high-speed rail network goes from strength to strength 
45 Darynaufal Mulyaman \& Kanya Damarçanti | Comparative Analysis of The Indonesia-China High-Speed Train Project and The KTX Korea-France: A Sustainable Development for Locals or Reconfiguring Other Interests

https://www.globalrailwayreview.com/article/61 573/ktx-south-koreas-high-speed-rail/ (Accessed on April 11, 2021)

Lukihardianti, Arie. (2016). Proyek Kereta Cepat, 57 Hektare Hutan Jabar Hilang https://nasional.republika.co.id/berita/nasional/d aerah/o19abl354/proyek-kereta-cepat57-hektare-hutan-jabar-hilang (Accessed on April 11, 2021)

Paendong, Meiki W. (2020). The JakartaBandung Rail Project: 5 Years On and Still Going Nowhere.

https://thediplomat.com/2020/12/the-jakartabandung-rail-project-5-years-on-and-still-goingnowhere/ (Accessed on April 11, 2021)

Prasetiyo, B. (2016). Pengamat: Proyek Kereta Cepat Merusak Lingkungan. Retrieved from https://bisnis.tempo.co/read/738527/pen gamat-proyek-kereta-cepat-merusaklingkungan (Accessed on July 12, 2019)

PT. Kereta Cepat Indonesia Cina. (2016). Konsep Pembangunan Terintegrasi.

http://kcic.co.id/konsep-pembangunanterintegrasi/ (Accessed on July 13, 2019)

Rakhmat, Muhammad Zulfikar. Indonesia Makin Bergantung Pada Cina dan Itu Berbahaya: Apa Yang Bisa Dilakukan.

https://theconversation.com/indonesia-makinbergantung-pada-cina-dan-ituberbahaya-apa-yang-bisa-dilakukan150948 (Accessed on April 11, 2021)

Rezkisari, Indira. (2015). Bangun Kereta Cepat, Konsorsium BUMN-Cina Dibentuk. https://republika.co.id/berita/ekonomi/m akro/15/10/16/nwarda328-bangun- kereta-cepat-konsorsium-bumn-cinadibentuk (Accessed July 24, 2019).

Saeno. (2016). Kereta Cepat Jakarta-Bandung: KCIC Siap Hadapi Gugatan Walhi. https://ekonomi.bisnis.com/read/20160219/98/5 20699/kereta-cepat-jakarta-bandungkcic-siap-hadapi-gugatan-walhi (Accessed on April 11, 2021)

Sihite, Ezra and Novy Lumanauw. (2015). China Says Its High-Speed Railway Package for Indonesia Is 'More Competitive' Than Japan's.

https://jakartaglobe.id/business/china-says-highspeed-railway-package-indonesiacompetitive-japans/ (Accessed on April 11, 2021)

Sutianto, Feby Dwi. (2016). Pengembang Kereta Cepat Jakarta-Bandung Suntik Modal Rp $1,25 \quad T$. https://finance.detik.com/beritaekonomi-bisnis/d3116023/pengembang-keretacepatjakarta-bandung-suntik-modal-rp125-t (Accessed April 3, 2019)

Syailendra, E. A. (2015). Indonesia's HighSpeed Rail: A China-Japan Scramble for Influence? RSIS Commentary No. 2699 December 2015.

http://futuredirections.org.au/wpcontent/uploads/2016/01/CO15269.pdf

(Accessed on July 23, 2019)

Tritto, Angela. (2020). Contentious Embeddedness: Chinese State Capital and the Belt and Road Initiative in Indonesia.

https://madeinchinajournal.com/2020/05/06/cont entious-embeddedness-chinese-state- 
capital-indonesia/ (Accessed on April

11, 2021)

Yafei, H. (2014). China's Overcapacity Crisis Can Spur Growth Through Overseas Expansion.

https://www.scmp.com/comment/insightopinion/article/1399681/chinasovercapacity-crisis-can-spur-growththrough-overseas (Accessed on July 22, 2019)

Yati, Rahmi. (2021). Kereta Cepat Jakarta Bandung Terapkan Teknologi Tinggi Menhub Minta Transfer Knowledge. https://ekonomi.bisnis.com/read/202104 11/98/1379402/kereta-cepat-jakartabandung-terapkan-teknologi-tinggimenhub-minta-transfer-knowledge (Accessed on April 11, 2021) 